\title{
Economics
}

2018; 7(3): 47-55

http://www.sciencepublishinggroup.com/j/eco

doi: 10.11648/j.eco.20180703.11

ISSN: 2376-659X (Print); ISSN: 2376-6603 (Online)

Case Report

\section{Professional Training in Reducing the Phenomenon of Unemployment in Algeria Econometric Study (1970-2016)}

\author{
Wahiba Halimi \\ Department of Management, University Abou Bekr Belkaid, City of Tlemcen, Algeria \\ Email address: \\ halimi_wahiba@yahoo.fr
}

To cite this article:

Wahiba Halimi. Professional Training in Reducing the Phenomenon of Unemployment in Algeria Econometric Study (1970-2016). Economics. Vol. 7, No. 3, 2018, pp. 47-55. doi: 10.11648/j.eco.20180703.11

Received: October 21, 2018; Accepted: December 21, 2018; Published: January 23, 2019

\begin{abstract}
The professional training sector in Algeria is a vital sector and has achieved many goals despite the shortage and lack of means and the difficulty of obstacles that hampered its career. Professional training in Algeria has been able to make important strides in order to develop human potential and expand energy through the establishment and creation of centers and institutes to respond to the growing social demand for training. The State has paid attention to it through funding, making huge expenditures for the success of this training process raising the challenges of ignorance and unemployment). The present paper deals with the probable influence of the professional training on the unemployment by an econometric study between $1970-2016$.
\end{abstract}

Keywords: Professional Training, Expenses Composition, Unemployment, Econometric Study

\section{Introduction}

The professional training sector, a vital sector attached to the public authorities have high hopes for his help to fight unemployment in various forms, and the achievement of sustainable development calls provide for the human element through the allocation of a significant credit and its composition and preparation for entry to work through the rehabilitation of the labor market Making them compete with foreign labor. Based on what has already been able to formulate the following dilemma: How effective professional training in reducing the phenomenon of unemployment in Algeria during the period 1970-2012?

To address this problem, the following hypotheses were adopted:

1. The expenses of training play a role in mitigation of the unemployment rate.

2. The expenditure of training and other variables are consistent with the total expenditure of public investment, inflation, GDP per capita and the combined change in the unemployment rate.

\section{Professional Training and Unemployment: Theoretical Reading}

\subsection{Professional Training in Algeria}

\subsubsection{The Concept of Professional Training}

It means all Professional training aims (action both for the functional education of the trainees, for the training of the foundation, for the complementary or assigned training, for the improvement of the professional. This work can be organized in whole or in part in the fields of work or at the level of organized structures in the institution or relying solely on special means of the training organization. It is a factor that means enabling him to implement the status of his work list. If he is able to do so, his professional composition may be considered to have ended no matter what year. Gilbert As for the definition of technical education, the formation of a multiple is found to be beneficial to the individual and allows him to adapt to the various professional situations presented to him by the institution. [1]

As defined [2], the vocational training includes all forms of preparation or modification of a professional work, both 
in the teaching of knowledge and the transfer of ethical values or professional knowledge related to this profession. On the other hand, Mr. Tayyib al-Khudairi defined it as: In some Arab countries by vocational training, prepare individuals professionally, and train them in certain occupations in order to raise their production level and acquire new skills. [3]

\subsubsection{The Stages Experienced by the Professional Training Sector}

\section{i. The Beginning of Training in Algeria: 1962-1979}

1962 - 1979 B stage is characterized by a classical group of specialized institutions in training and some high schools and technical nature of professional schools that are the product of colonialism, it was the economic motor in 1967, which was the implementation of national plans and programs to create a reason The need for qualified labor in various fields and given the paucity and lack of manpower qualified hand during this period has been training rapidly for workers in short courses, but for the upper frames were incomplete at the level of (ministries and public institutions) have been formative Through the establishment of common structures for training between these sectors. [4]

\section{ii. Expansion of Vocational Training 1980-1989}

Algeria has made tremendous efforts to develop the professional training sector after independence in order to cover the shortage of labor. During this period, professional training was characterized by the emergence of two new modes: And remote configuration 1982 and 1985 was the year for the launch of this was the basic types their aim is to raise vocational training opportunities and adapting them to the needs of the market Alaml. kma characterized this period marked the evolution due to the completion of important structures and the diversity of patterns of professional training. It distinguishes between [5]:

Termination Formation:

This configuration is highly visible in professional training centers and trainees where the number exceeded these centers 70 centers in 1979 to reach 343 centers in 1989 and the number of trainees reached 113,000 registered and 6599 Professor in 1989.

\section{Composition through Taming:}

This pattern is characteristic of young people between the ages of 15 and 18 years and has known this type some of the disadvantages during the period of expansion of vocational training because of the lack of respect for the book of conditions linking the vocational training institutions to exploiters and the absence of practical texts that have not been in a few The number of trainers reached 200, and as a result of the low frequency of economic activity in 1986, the number of skilled workers dropped to 72,000.

Correspondence configuration:

This type of formation was characterized by a remarkable increase in the number of registrants during the period 1987, reaching 10.314 registered. The number of correspondents increased to 16,000 correspondents in 1989. This type has been identified in several shortcomings:

Low total specialties offered.

To determine the certificates granted after graduation in the certificate of professional competence and led to low interest in this type of training by the candidates.

\section{iii. Professional Training and Market Economy (1990 - Present)}

The 1990s witnessed several changes, the most important of which were economic reforms that led to the transition from the economy directed to the market economy. These reforms focused on the vocational training sector in order to provide the necessary means for the national apparatus to adapt to the economic and social transformations.

Defining the role of the state in planning and managing strategic functions and enhancing the role of the economic and social partners on the issues related to training.

This stage also witnessed many developments in terms of the number of basic establishments and the preparation of trainees, whether in the public sector for vocational training or at the level of the newly-established private sector. Its main tasks were as follows:

Preparing young people and adults who wish to obtain work or workers who wish to reintegrate them.

Meet the part of the configuration request which is constantly increasing due to the high number of scissors of the educational system.

The professional training sector has undergone several transformations and large expansions during the beginning of the current century in 2002. It started to modernize the sector by rehabilitating it in order to rehabilitate the vocational training and adapt it to the needs of the labor market and increase the performance of its centers and institutes and the management of institutions by introducing automated media at the level of administrative departments. And the establishment of an observatory for professional training and work aimed at harmonizing the sector with the socio-economic environment. The sector has taken professional training in several aspects, the most important of which are:

To meet the needs of the national economy of qualified manpower.

Meeting the needs of foreign customers.

Open up to modern professional techniques.

\subsubsection{Professional Training System in Algeria}

The vocational training system in Algeria consists of four networks, which include each network of independent institutions: [6]

\section{i. Network of Public Institutions for Vocational Training}

represented in: Training Centers: 735 centers numbering, allocated in the national vocational training institutes Numbering 93 centers, the National Institute for Vocational Training is to create and improve the level of trainers And contributes to the preparation and distribution of vocational training, Center for Studies and Research in the professions and qualifications: prepares studies on qualifications and their 
development. National Institute to develop and upgrade continuous configuration: The pedagogic assistance and technology for economic institutions in order to upgrade and develop continuous training. National Center for the Development of Taming and Continuing Training: His duties are to develop the financial and financial resources and conduct the media activities.

\section{ii. Private Schools Network}

Natural and moral persons under private law Establish institutions for training and education.

\section{iii. Network of Public Institutions for Vocational Training of Other Ministries}

There are 70 institutions training 23,500 workers per year or trainees in the sectors of agriculture, health industry, fishing, postal and communication, youth and sports.

\section{iv. Network of Training Institutions of Economic Companies}

This network includes the training schools of the major institutions in the field of energy, mining and industry with a capacity of 13,000 formation.

\subsection{The Unemployment}

\subsubsection{The Concept of Unemployment: [7]}

\section{i. Definition of the International Labor Office BLT}

Based on three conditions when available, the person is considered a hero:

1. Without work: works without pay.

2. Immediate work climate: Can do work immediately.

3. Looking for a job: Searching during a certain period on paid work.

The definition of the World Bank: "Unemployed is everyone who is able to work and willing and looking for it and accept it at the prevailing wage level, but to no avail."

\section{ii. Types of Unemployment}

Unemployment forms and types are mentioned in the following points

- Incertain, explicit or apparent unemployment:

It refers to the situation in which the breakdown of work is apparent and it suffers from it is part of the available labor force, ie, the presence of a large number of individuals who are able to work and willing and seeking the prevailing wage level, but to no avail. This type of unemployment appears in excess supply In the labor market by demand. [8]

Seasonal unemployment:

Means the irregularity of work for certain categories of youth and adults in certain seasons as is the case in the agricultural sector where there is a time gap between each crop and the next. [9]

-Periodic unemployment:

This type of unemployment spreads in the advanced capitalist countries whose economy is exposed to crises resulting from the decline in actual demand, which leads to the disruption of a large part of the production capacity of the national economy and thus the spread of unemployment among workers.[10]

-Structural unemployment:

This type of unemployment is manifested by the incompatibility of competencies and jobs when the patterns of demand and production change due to the economic fluctuations in the structure of the economy, such as the discovery of new resources or more efficient means of production or the emergence of new goods to replace old goods. Harmonized with available employment opportunities there is a significant reduction in consumer demand.[11]

- Friction unemployment:

Fractional unemployment here means that job seekers and employers who have job opportunities are looking at each other through advertisements in newspapers, direct contacts, employment offices, and the search period may be prolonged due to lack of sufficient information or lack of information on both sides.[12]

\section{iii. Causes of Unemployment Phenomenon Represent the \\ Following Points: [13]}

Population growth and increase, economic stagnation, employment reduction policy, shortening of technology for time and effort and completion of work quickly and accurately and at a lower cost to replace labor, high illiteracy rates due to lack of education., The disappearance of some old artisans and handicrafts, the reluctance of many learners and graduates to manual labor and preference for office work, rapid technological development has led to the elimination of a large number of work, imbalance and gap and lack of coordination between education policies and development needs and the labor market and development plans.

\subsubsection{Policies Adopted by Algeria to Combat Unemployment}

One of the most important policies or roles Algeria must play to overcome the problem of unemployment is:[14]:

-Creating new job opportunities for young people.

- Increasing transfer and vocational training programs in the field of entrepreneurship and crafts.

-The balance of the state between the proportions of the graduates and the real needs of them and the transfer of surplus to other areas after being trained in new professions.

-Encourage young people to work in other non-governmental sectors with the necessary protection for them to achieve psychological stability.

-The management of borrowing to young people, whether from the state or from banks, and have a low interest rate.

-Development of small enterprises and directing a large part of investments to many projects.

-Support the ongoing training process especially training and qualification.

-Encourage small and medium enterprises and industries and open markets for their products to create jobs.

-Expanding the establishment of new industrial cities and industrial areas to attract investments. 


\section{Algeria Case study 1970-2016}

\subsection{Method and Tools}

\subsubsection{Method: Time Series Study}

\section{i. Time Series Properties}

- Randomity: It is a random component that must have been generated from random conditions. It expresses irregular fluctuations. The random component can be detected either by analyzing the data graphically or by using statistical tests. However, this method does not clearly show us this component so we will resort to:

-Stability [15]

The spread of the time series can determine the stability or instability of the chain. The time series is stable, if oscillated around a fixed arithmetic mean, with a variation that has no relation to time and its common variations are constant in the sense that:

$$
\begin{aligned}
& E\left(Y_{t}\right)=E\left(Y_{t+k}\right)=\mu \\
& \operatorname{VAR}\left(Y_{t}\right)=\operatorname{VAR}\left(Y_{t+k}\right)=\gamma_{0} \\
& \operatorname{COV}\left(Y_{t}, Y_{t+k}\right)=\operatorname{COV}\left(Y_{t+k}, Y_{t+k+s}\right)=\gamma_{1}
\end{aligned}
$$

The stable time series does not contain either a general trend or seasonal variations and a constant variation.

-Time series types are unstable

TS Trend stationary

Write on the form $y_{t}=\mu+\beta t+\varepsilon_{t}$

With a white error. The string is unstable because it is time dependent.

In order to convert these strings into stable chains, we follow the regression method.

DS Differency stationary

The relationship of the general trend is unclear and its variation varies over time. To return the time series stable we use the variance method

\section{ii. Stability Test: [16]}

Test Dickey Fuller 1979

Content: This test allows you to know that the string is stable or not and to specify the type of unstable time series of the type TS or DS

The principle of this test is represented in:

$H_{0}: \varphi_{1}=1$ The time series is unstable

$\left|\varphi_{1}\right|<1 \mathrm{H}$ Time series stable.

* Self-regression model:

* Self-regression model with a constant:

* Self-regression model with a general trend:

$$
\begin{gathered}
y_{t}=\varphi_{1} y_{t-1}+\varepsilon_{t} \\
y_{t}=\varphi_{1} y_{t-1}+B+\varepsilon_{t} \\
y_{t}=\varphi_{1} y_{t-1}+B t+c+\varepsilon_{t}
\end{gathered}
$$

We estimate $\phi \mathrm{Bc} \phi \mathrm{a}$ To capacity in a manner MCO For Forms 1,2 and 3.

As well as the standard deviation of each model in a manner MCO.

$$
t_{\varphi \wedge 1}=\frac{\varphi \wedge 1}{\sigma_{\varphi \wedge 1}}
$$

if it was $t_{t a b} \quad \geq_{1} \phi \quad t$ We accept ${ }_{0} H$ And we refuse $H_{1}$ That means there is Walls alone.

Test of Phillips \& Perron [17]

The steps of this test are as follows:

1. Estimation by means of the three squares method Dicke $\mathrm{y}$-Fuller In order to assess the rest $\mathrm{e}_{\mathrm{t}}$ :

$$
\hat{\sigma}^{2}=\frac{1}{n} \sum_{t=1}^{n} e_{t}^{2}
$$

2. Estimating short-term variability:

3. Estimation of long-term variability: $s_{t}^{2}=\frac{1}{n} \sum_{t=1}^{n} e_{t}^{2}+2 \sum_{i=1}^{l}\left(1-\frac{i}{l+1}\right) \frac{1}{n} \sum_{t=1}^{n} e_{t} e_{t-i}$

In order to estimate this variability in the long run, it is important to determine the delay figure 1 , and is roughly equal to:

$\mathrm{L}=4$ (n / 100) 2/9 whereas $n$ Views

4. Statistical calculation

$$
t_{\hat{\varphi}_{1}}^{*}=\sqrt{k} * \frac{\left(\hat{\varphi}_{1}-1\right)}{\hat{\sigma}_{\hat{\varphi}_{1}}}+\frac{n(k-1) \hat{\sigma}_{\hat{\varphi}_{t}}}{\sqrt{k}}
$$

Where $k=\frac{\hat{\sigma}^{2}}{s_{t}^{2}}$

Compare this statistic with the tabular value in a table Makinon.

If $t_{\hat{\varphi}_{1}} \geq t_{T A B}$ we accept the nihilistic hypothesis $\varphi_{1}=1: H_{0}$ the time series is unstable. We reject the alternative hypothesis $\varphi_{1}<1: H_{1}$ The time series is stable.

\section{iii. Self-Linking Concept [18]}

Self-correlation indicates a correlation between the observed values for the same variable.

-Self-correlation function: This function is concerned with studying the relationship between the time series itself, ie the detection of the internal correlations of the time series. Let it be (Yt) Stable time series k Delay coefficient, determines the self - correlation relationship :

$$
\rho(k)=\frac{\sum_{t=1}^{N-k}\left(y_{t}-\bar{y}\right)\left(y_{t+k}-\bar{y}\right)}{\sum_{t=1}^{N}\left(y_{t}-\bar{y}\right)^{2}}
$$

Where $\bar{y}$ Represents the 
$\underset{\text { arithmetic mean }}{\bar{y}}=\frac{1}{N} \sum_{t=1}^{N} y_{t}$

formulated in terms of variation and common variation:

$$
\rho(k)=\frac{\operatorname{COV}\left(y_{t}, y_{t+k}\right)}{\sqrt{\operatorname{VAR}\left(y_{t}\right) \cdot \operatorname{VAR}\left(y_{t+k}\right)}}
$$

It is therefore observed that self-correlation measures the degree of correlation between Time series values

1. Characteristics of self-correlation :

2. Self-symmetric correlation around zero means that: $\rho(k)=\rho(-k)$

3. Self-association is between the values: $-1 \leq \rho(k) \leq+1$

$$
-1 \leq \rho(k) \leq+1
$$

4. When $\mathrm{k}=0$ The.

Thus correlating the Tam chain

5. For the benefit of the account $(\mathrm{k})$ when the time series is unstable.

6. We choose the degree of delay Depending on the number of views available and specified in relation $\mathrm{k}=\mathrm{T} / 4$

\subsubsection{Tools}

Based on previous studies and theoretical literature, an attempt will be made to test the causal relationship between unemployment and vocational training (DEPFOR) But with additional variables we mention total spending (GS), GDP per capita (GDPC), Inflation (INF) Public investment(INV) As independent variables that can give a significant explanation of unemployment And will depend on the program eviews8 In order to address time series with the adoption of the time period between $1970-2016$.

\section{i. Choice of the Model's Variables}

Economic thought in the shadow of the neutral state included the exclusion of the state from interfering in all economic activities beyond its traditional functions of defense (security) and justice in the form of the judicial facility.[19] However, as he developed this thought, some came to speak For the assignment of new tasks such as the distribution of public expenditures, ie, the amounts of money spent [20] and within a period of time to satisfy the general needs of the society [21], and shall be ordered to spend a representative body of public law [22]. And is then subjected to distribution to the control of the legislature, the executive and the judicial process [23] and different control process by changing the types of expenses that were special to governance or investment [24] or administrative [25], real [26], or transformative [27]. This difference in the method of control is due to the impact of these expenditures, as it extends to the total consumption of consumption [28], and even distribution of national income [29].

From this point of view and relying on The economic theory In the first and second studies, the cost of vocational training was approved (DEPFOR) Since expenditure is the direct instrument of the State to control any sector as previously added Other variables affect the unemployment rate(Unem) We mention total spending (GS), GDP per capita (GDPC), Inflation (INF) Which represents a rise in prices leading to a gap between the volume of goods available and the amount of income available to spend and increase the monetary demand for goods offered, or in the economic sense is the weakness of the purchasing power of the currency [30], Public investment (INV) Means the use of funds in economic, social and cultural projects in order to achieve new capital and raise productive capacity and compensation of old capital [31], And is also the use of assets in the establishment of new projects come from behind the return or additional benefit to it is an investment activity involving the exercise of business resulting in an agreement and result in the formation of investment assets can be operated and benefit for periods of time [32].

As $\hat{A}$ relies $\mathrm{T}$ study of the quantitative approach the standard appropriate to study the effect of independent variables on the dependent variable, and through the use of the least squares method entirely corrected Fully modified least squares (FMOLS). A certified study in the collection of data is the basic annual basis (1970-201 6) and was the source of this information the World Bank.

\section{ii. Form Drafting}

The form is formulated as follows:

Unem $_{\mathrm{t}}=\mathrm{f}\left(\mathrm{GS}_{\mathrm{t}}\right.$, GDPC $_{\mathrm{t}}$, DEPFOR $\left._{\mathrm{t}}, \mathrm{INV}_{\mathrm{t}}\right) \ldots \ldots$

Where:

Unemployment rate per year $t$ Representative in Unemt

Total expenditure rate per year $t$ Representative in GSt

Gross output per capita per year $t$ Representative in GDPCt

Rate of vocational training expenditure per year $t$ Representative in DEPFORt

The rate of public investment per year $t$ Representative in INVt

Inflation rate per year $t$ Representative in INFT

\section{iii. Studying the Stability of Time Series}

The first phase of this study relates to the characteristics of time series (without general direction, single walls, general direction vehicle, monolithic walls) ADF Dicky Forl enlarged and PP Phillips Peron reveals how stable the time series is based on level or origin (level) And on the basis of the first difference ( $1^{\text {st }}$ differences) And second differences (2 ${ }^{\mathrm{dn}}$ differences) It is essential that the time series be stable at the same level to talk about synchronous integration at this stage using two tests ADF And PP To conduct the unitary root test. The time series models are presented according to the lower squares method as follows:

For unemployment Unem:

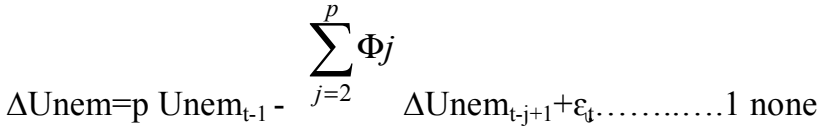

$$
\begin{aligned}
& \sum_{j=2}^{p} \Phi j \\
& \Delta \text { Unem }=\mathrm{p} \quad \text { Unem }_{\mathrm{t}-1} \quad-\quad{ }_{j=2} \quad \Delta \mathrm{Unem}_{\mathrm{t}-\mathrm{j}+1}+\mathrm{c}+\varepsilon_{\mathrm{t}} \ldots \ldots . .2
\end{aligned}
$$


$\Delta \mathrm{Unem}_{=\mathrm{p}} \quad \mathrm{Unem}_{\mathrm{t}-1}-\sum_{j=2}^{p} \Phi j$ trend \& intercept

For global spending GS):

$\Delta \mathrm{GS}=\mathrm{p} \mathrm{GS}_{\mathrm{t}-1}-\sum_{j=2}^{p} \Phi j \mathrm{GS}_{\mathrm{t}-\mathrm{j}+1}+\varepsilon_{\mathrm{t}} \ldots \ldots \ldots \ldots 1$ none

$\Delta \mathrm{GS}=\mathrm{p} \mathrm{GS}_{\mathrm{t}-1-} \sum_{j=2}^{p} \Phi j \mathrm{GS}_{\mathrm{t}-\mathrm{j}+1}+\mathrm{c}+\varepsilon_{\mathrm{t}} \ldots \ldots . .2$ intercept

$\Delta \mathrm{GS}=\mathrm{p} \mathrm{GS}_{\mathrm{t}-1}-\sum_{j=2}^{p} \Phi j \mathrm{GS}_{\mathrm{t}-\mathrm{j}+1}+\mathrm{c}+\mathrm{b}_{\mathrm{t}}+\varepsilon_{\mathrm{t}} \ldots \ldots .3$ trend \& intercept

Gross domestic product Per capita GDPC):

$\Delta \mathrm{GDPC}=\mathrm{p} \mathrm{GDPC}_{\mathrm{t}-1}-\sum_{j=2}^{p} \Phi j$ none

$\Delta \mathrm{GDPC}=\mathrm{p} \mathrm{GDPC}_{\mathrm{t}-1-} \sum_{j=2}^{p} \Phi j$ intercept

$\Delta \mathrm{GDPC}=\mathrm{p} \mathrm{GDPC}_{\mathrm{t}-1-} \sum_{j=2}^{p} \Phi j \mathrm{GDPC}_{\mathrm{t}-\mathrm{j}+1}+\mathrm{c}+\mathrm{b}_{\mathrm{t}}+\varepsilon_{\mathrm{t}} \ldots \ldots .3$ trend \& intercept

For professional training expenses DEPFOR):

$\Delta$ DEPFOR $=\mathrm{p} \mathrm{DEPFOR}_{\mathrm{t}-1-1} \sum_{j=2}^{p} \Phi j$ none

$\triangle$ DEPFOR $=\mathrm{p}_{\text {DEPFOR }} \mathrm{t}-1_{-} \sum_{j=2}^{p} \Phi j \Delta$ DEPFOR ${ }_{\mathrm{t}-\mathrm{j}+1}+\mathrm{c}+\varepsilon_{\mathrm{t}} .2$ intercept

$\Delta \quad$ DEPFOR $=\mathrm{p}$ DEPFOR $\mathrm{t}-1 \quad-\quad \sum_{j=2}$ $\mathrm{GDPC}_{\mathrm{t}-\mathrm{j}+1}+\mathrm{c}+\mathrm{b}_{\mathrm{t}}+\varepsilon_{\mathrm{t}} \cdot 3$ trend \& intercept

For public investment ( INV):

$\Delta$
$\Delta \mathrm{INV}=\mathrm{p} \mathrm{INV}_{\mathrm{t}-1-} \sum_{j=2}^{p} \Phi j$

$\sum_{j=2}^{p} \Phi j$

$\Delta \mathrm{INV}=\mathrm{p}_{\mathrm{INV}} \mathrm{t}-1_{-1} \quad \sum_{j=2} \Delta \mathrm{INV}{ }_{\mathrm{t}-\mathrm{j}+1}+\mathrm{c}+\varepsilon_{\mathrm{t}} \ldots \ldots \ldots .2$ intercept

$\Delta \mathrm{INV}=\mathrm{p} \mathrm{INV} \mathrm{t}-1^{-} \sum_{j=2}^{p} \Phi j$ intercept

For inflation (INF):

$\Delta \mathrm{INV}=\mathrm{p} \mathrm{INV}_{\mathrm{t}-1-} \sum_{j=2}^{p} \Phi j$

$\Delta \mathrm{INV}={\mathrm{p} \mathrm{INV} \mathrm{t}-1-\sum_{j=2}^{p} \Phi j}_{\Delta \mathrm{INV}_{\mathrm{t}-\mathrm{j}+1}+\mathrm{c}+\varepsilon_{\mathrm{t}} \ldots \ldots . .2}$ intercept

$\Delta \mathrm{INV}=\mathrm{p} \mathrm{INV}_{\mathrm{t}-1} \sum_{j=2}^{p} \Phi j$ intercept

Where:

1- UNEM $\Delta$ : The first differentiation rate of unemployment.

2- GS $\Delta$ : The first differentiation rate total spending.

3- GDPC $\Delta$ : The first differentiation rate of GDP per capita.

4- DEPFOR $\Delta$ : The first differentiation rate of vocational training expenses.

5- INV $\Delta$ : The first differentiation rate of public investment.

6- INF $\Delta$ : The first differentiation rate of inflation.

$\mathrm{P}$ : The number of collisions was analyzed in this study using a coefficient modified AIC

(1): A form of self - regression of the first class.

(2): A form of self - regression that there was conclusive.

(3): Self-regression model with segmental and general direction.

\subsection{Results and Discussion}

\subsubsection{Test the Stability of Time Series: Single Root Test} 1. Test ADF:

Level:

Table 1. Test ADF - the level.

\begin{tabular}{|c|c|c|c|c|c|c|}
\hline \multirow{2}{*}{ Series } & & \multicolumn{3}{|c|}{ T cal } & \multirow[b]{2}{*}{$10 \%$} & \multirow{2}{*}{ the decision } \\
\hline & & T-stati & $1 \%$ & $5 \%$ & & \\
\hline \multirow{3}{*}{$\begin{array}{l}\text { Total expenditure } \\
\text { GS }\end{array}$} & None & 0.174 & -2.621 & -1.948 & -1.611 & Unstable \\
\hline & Intercept & $2.516-$ & -3.600 & -2.935 & -2605 & Unstable \\
\hline & $\mathrm{I} \& \mathrm{~T}$ & $2.962-$ & -4.198 & -3.523 & -3.192 & Unstable \\
\hline \multirow{3}{*}{$\begin{array}{l}\text { DEPFOR(Vocational } \\
\text { training expenses): }\end{array}$} & $\mathrm{N}$ & -1.282 & 2.625 & -1.949 & -1.611 & Unstable \\
\hline & I & -6.218 & -3.600 & -2.935 & -2605 & stable \\
\hline & $I \& T$ & -4.098 & -3.523 & -3.192 & 3.209 & stable \\
\hline \multirow{3}{*}{ GDPC } & $\mathrm{N}$ & 7.188 & -2.621 & -1.948 & -1.611 & stable \\
\hline & I & -1.077 & -3.596 & 2.933 & -26.604 & Unstable \\
\hline & $I \& T$ & -1.909 & -4.198 & -3.523 & 3.192 & Unstable \\
\hline
\end{tabular}




\begin{tabular}{lllllll}
\hline \multirow{2}{*}{ Series } & & \multicolumn{3}{c}{ T cal } & & \multicolumn{2}{c}{ the decision } \\
\cline { 2 - 7 } & & T-stati & $\mathbf{1 \%}$ & $\mathbf{5 \%}$ & $\mathbf{1 0 \%}$ & Unstable \\
Inflation & $\mathrm{N}$ & -1.233 & -2.621 & -1.948 & -1.611 & Unstable \\
& I & -2.099 & -3.596 & -2.933 & -26.604 & Unstable \\
\multirow{3}{*}{ Public investment } & I \& T & -2.129 & -4.192 & -3.520 & 3.191 & Unstable \\
& N & -0.676 & -2.621 & -1.948 & -1.611 & stable \\
\multirow{3}{*}{ The unemployment } & I & -3.798 & -3.596 & -2.933 & -26.604 & Unstable \\
& I \& T & -3.917 & -4.192 & -3.520 & -3.192 & Unstable \\
& N & -0.974 & -2.621 & -1.948 & 1.611 & stable \\
\hline
\end{tabular}

Unit differences

Table 2. Test ADF - Unit differences.

\begin{tabular}{|c|c|c|c|c|c|c|}
\hline \multirow{2}{*}{ Series } & & \multicolumn{3}{|c|}{ T cal } & \multirow[b]{2}{*}{$10 \%$} & \multirow{2}{*}{ the decision } \\
\hline & & T-stati & $1 \%$ & $5 \%$ & & \\
\hline \multirow{3}{*}{$\begin{array}{l}\text { Total expenditure } \\
\text { GS }\end{array}$} & None & -6.296 & -2.622 & -1.949 & -1.611 & stable \\
\hline & Intercept & -6.255 & -3.600 & 2.935 & -2605 & stable \\
\hline & $I \& T$ & $6.189-$ & 4.198 & $3.523-$ & $3.192-$ & stable \\
\hline \multirow{3}{*}{$\begin{array}{l}\text { DEPFOR(Vocational } \\
\text { training expenses): }\end{array}$} & $\mathrm{N}$ & -16.978 & -2.621 & -1.948 & -1.611 & stable \\
\hline & I & -8.027 & $3.596-$ & -2.933 & -26.604 & stable \\
\hline & $I \& T$ & $7.920-$ & $4.192-$ & 3.520 & $3.191-$ & stable \\
\hline \multirow{3}{*}{ GDPC } & $\mathrm{N}$ & $2.866-$ & 2.622 & $1.949-$ & $1.611-$ & stable \\
\hline & I & $5.521-$ & $3.600-$ & $2.935-$ & $2.605-$ & stable \\
\hline & $I \& T$ & $5.651-$ & $4.198-$ & 3.523 & $3.192-$ & stable \\
\hline \multirow{3}{*}{ Inflation } & $\mathrm{N}$ & $6.121-$ & $2.600-$ & 1.949 & $1.611-$ & stable \\
\hline & I & $6.047-$ & $3.600-$ & $2.935-$ & $2.605-$ & stable \\
\hline & $I \& T$ & 5.991. & $4.198-$ & $3.523-$ & $3.192-$ & stable \\
\hline \multirow{2}{*}{ Public investment } & $\mathrm{N}$ & 9.392 & $2.622-$ & $1.949-$ & $1.611-$ & stable \\
\hline & I & $9.274-$ & $3.600-$ & $2.935-$ & $2.605-$ & stable \\
\hline \multirow{4}{*}{ The unemployment } & $\mathrm{I} \& \mathrm{~T}$ & $7.129-$ & $4.205-$ & 3.526 & 3.194 & stable \\
\hline & $\mathrm{N}$ & $5.693-$ & $2.622-$ & 1.949 & $1.611-$ & stable \\
\hline & I & $5.669-$ & $3.600-$ & $2.935-$ & $2.605-$ & stable \\
\hline & $\mathrm{I} \& \mathrm{~T}$ & $5.575-$ & $4.198-$ & $3.522-$ & 3.192 & stable \\
\hline
\end{tabular}

as tcal $<$ ts For the three models at the confidence levels of $1 \%, 5 \%$ and $10 \%$ to all TB Celle time we say, then, that the latter is stable when the first test by differences ADF.

\section{Test (PP)}

Level:

Table 3. Test $P P$ - the level.

\begin{tabular}{|c|c|c|c|c|c|c|}
\hline \multirow{2}{*}{ Series } & & \multicolumn{3}{|c|}{ T cal } & \multirow[b]{2}{*}{$10 \%$} & \multirow{2}{*}{ the decision } \\
\hline & & T-stat & $1 \%$ & $5 \%$ & & \\
\hline \multirow{3}{*}{$\begin{array}{l}\text { Total expenditure } \\
\text { GS }\end{array}$} & None & 0.545 & $2.621-$ & $1.948-$ & $1.611-$ & Is stable \\
\hline & Intercept & $2.503-$ & $3.596-$ & $2.933-$ & $2.604-$ & Unstable \\
\hline & $I \& T$ & $2.955-$ & $4.192-$ & $3.520-$ & $3.191-$ & Unstable \\
\hline \multirow{3}{*}{$\begin{array}{l}\text { DEPFOR(Vocational } \\
\text { training expenses): }\end{array}$} & $\mathrm{N}$ & $2.385-$ & $2.621-$ & $1.948-$ & $1.611-$ & Unstable \\
\hline & I & $8.028-$ & $3.596-$ & $2.933-$ & $2.605-$ & Unstable \\
\hline & $I \& T$ & $7.920-$ & $4.195-$ & $3.520-$ & $3.191-$ & Unstable \\
\hline \multirow{3}{*}{ GDPC } & $\mathrm{N}$ & 6.288 & $2.621-$ & $1.948-$ & 1.611 & Unstable \\
\hline & I & 1.043 & $3.596-$ & $2.933-$ & $2.604-$ & Unstable \\
\hline & $I \& T$ & $1.664-$ & $4.192-$ & $3.520-$ & $3.191-$ & Unstable \\
\hline \multirow{3}{*}{ Inflation } & $\mathrm{N}$ & 1.248 & $2.621-$ & $1.948-$ & $1.611-$ & Unstable \\
\hline & I & $2.188-$ & $3.596-$ & $2.933-$ & $2.604-$ & Unstable \\
\hline & $\mathrm{I} \& \mathrm{~T}$ & $2.205-$ & $4.192-$ & 3.520 & 3.192 & Unstable \\
\hline \multirow{2}{*}{ Public investment } & $\mathrm{N}$ & $0.397-$ & $2.621-$ & $1.948-$ & $1.611-$ & Unstable \\
\hline & I & $3.722-$ & $3.596-$ & $2.933-$ & $2.604-$ & stable \\
\hline \multirow{4}{*}{ The unemployment } & $I \& T$ & $3.664-$ & $4.192-$ & $3.520-$ & 3.191 & Unstable \\
\hline & $\mathrm{N}$ & $0.977-$ & $2.621-$ & $1.948-$ & $1.611-$ & Unstable \\
\hline & I & $1.400-$ & $3.596-$ & $2.933-$ & $2.604-$ & Unstable \\
\hline & $I \& T$ & $1.437-$ & 4.192- & $3.520-$ & $3.191-$ & Unstable \\
\hline
\end{tabular}

First differences 
Table 4. Test PP - First differences.

\begin{tabular}{|c|c|c|c|c|c|c|}
\hline \multirow{2}{*}{ Series } & & \multicolumn{3}{|c|}{ T cal } & \multirow[b]{2}{*}{$10 \%$} & \multirow{2}{*}{ the decision } \\
\hline & & T-stati & $1 \%$ & $5 \%$ & & \\
\hline \multirow{3}{*}{$\begin{array}{l}\text { Total expenditure } \\
\text { GS }\end{array}$} & None & $6.432-$ & $2.622-$ & $1.949-$ & $1.611-$ & stable \\
\hline & Intercept & $6.599-$ & $3.600-$ & $2.935-$ & $2.605-$ & stable \\
\hline & $I \& T$ & $6.522-$ & $4.198-$ & $3.523-$ & $3.192-$ & stable \\
\hline \multirow{3}{*}{$\begin{array}{l}\text { DEPFOR(Vocational } \\
\text { training expenses): }\end{array}$} & $\mathrm{N}$ & $16.978-$ & $2.621-$ & $1.948-$ & $1.611-$ & stable \\
\hline & I & $8.027-$ & $3.596-$ & $2.933-$ & $2.604-$ & stable \\
\hline & $I \& T$ & $7.920-$ & $4.192-$ & 3.520 & $3.191-$ & stable \\
\hline \multirow{3}{*}{ GDPC } & $\mathrm{N}$ & $2.690-$ & $2.622-$ & 1.949 & $1.611-$ & stable \\
\hline & I & $5.521-$ & $3.600-$ & $2.935-$ & $2.605-$ & stable \\
\hline & $\mathrm{I} \& \mathrm{~T}$ & $5.654-$ & $4.198-$ & $3.523-$ & $3.192-$ & stable \\
\hline \multirow{3}{*}{ Inflation } & $\mathrm{N}$ & $6.121-$ & $2.622-$ & $1.949-$ & $1.611-$ & stable \\
\hline & I & $6.047-$ & $3.600-$ & $2.935-$ & $2.605-$ & stable \\
\hline & $I \& T$ & 5.991. & $4.198-$ & $3.523-$ & $3.192-$ & stable \\
\hline \multirow{2}{*}{ Public investment } & $\mathrm{N}$ & 23.473- & $4.198-$ & $3.523-$ & $3.192-$ & stable \\
\hline & I & $22.382-$ & $3.600-$ & $2.935-$ & $2.605-$ & stable \\
\hline \multirow{4}{*}{ The unemployment } & $I \& T$ & 22.598 & $2.622-$ & $1.949-$ & $1.611-$ & stable \\
\hline & $\mathrm{N}$ & $5.664-$ & $2.622-$ & $1.949-$ & $1.611-$ & stable \\
\hline & I & $5.634-$ & $3.600-$ & $2.935-$ & $2.605-$ & stable \\
\hline & $\mathrm{I} \& \mathrm{~T}$ & $5.531-$ & $4.198-$ & $3.523-$ & $3.192-$ & stable \\
\hline
\end{tabular}

Since the time series are all stable at the first differences we say there is the possibility of a synchronous integration between these strings, to study the relationship in the long run, it must be verified that the chain of locks is stable at the level LEVE L By test ADF After estimating the modified lower squares, this will allow estimation of the function that links the time series between them.

\subsubsection{Test of Stationary of Residuum Using ADF}

Table 5. Testing the stationary of residuum using ADF.

\begin{tabular}{llllll}
\hline & & \multicolumn{3}{c}{ T cal } & \multirow{2}{*}{ the decision } \\
\cline { 1 - 5 } & T-stati & $\mathbf{1 \%}$ & $\mathbf{5 \%}$ & $\mathbf{1 0 \%}$ & \\
\hline None & -3.759 & -2.621 & -1.948 & $1.611-$ & stable \\
Intercept & $5.634-$ & $3.600-$ & $2.935-$ & $2.605-$ & stable \\
T \& I & $3.666-$ & $4.192-$ & $3.520-$ & $3.191-$ & Unstable \\
\hline
\end{tabular}

As the residuum series stabilized at confidence levels 1\%, 5\% and $10 \%$ ( None, Intercept) This means a common integration between the variables which there is a relationship in the long term, it can estimate the relationship between the variables in the long period using squares method of the junior entirely corrected ( FMDLS), Where the following relationship was obtained:

\section{$\mathrm{UNEM}=-0,583 \mathrm{INV}+0.122 \mathrm{INF}-0.374 \mathrm{GS}-0.50 \mathrm{GDPC}+$ 0.076 DEPFOR +54.324}

Indicates the value of the selection coefficient $\mathrm{R}^{2}=0.48$ There is an explanatory power for the independent variables under study for the dependent variable \% Of the change in the dependent variable represented in the unemployment as it shows from the results that the parameters of the estimated model have a statistical significance at the level of significance $5 \%$.

\section{Conclusions}

E $n$ the circumstances of harsh experienced by Algeria especially the period of the post -independence brought about negative effects, including widespread illiteracy, which almost touched all segments of society was obliged create and provide centers for education, leaving the expenses of general was its modernization sector, the formation by attracting larger The number of dropouts from public education through their formation and acquisition of knowledge, skills and competencies. This objective of the study to the Walt Presentation in to the importance of public spending and private $b$ vocational training sector and as well as the role played in reducing unemployment, and this study has reached the following conclusions:

1. Vocational training is a field that allows the study participants to obtain training and training in order to secure their future by creating a job opportunity. It also allows different departments and economic sectors to create their employees and improve their equipment.

2. The vocational training sector contributes to economic growth through the human resources it provides.

3. Reducing unemployment requires a relationship between training and the human resources it provides.

4. Reducing unemployment rates requires a relationship between vocational training and work in order to reconcile the demands of the labor market with the offers of job seekers qualifications and competencies.

5. The graduates of vocational training institutes have the opportunity or priority in assistance and funding for the creation of the institutions of the Formulate the year of thanks to the support of the National Agency for Youth Employment which are considered to be among all mechanisms or devices to combat unemployment.

Despite all the efforts and objectives achieved by the vocational training sector, it still suffers from weakness in its relationship with the labor market. The dissatisfaction of the labor market sectors to the level shown by the graduates of the centers and institutes, the State must give it the utmost importance so that it can achieve the goals set for him, 
including the rehabilitation of young people and their composition in order to enter the world of work and thus eliminate the problem of unemployment was One of the objectives of this study is to find out the extent to which this vital sector achieves the desired educational objectives in the field of knowledge by studying the training curricula.

\section{References}

[1] Mouloud Hashman : Models and techniques for short - term forecasting Duo said university publications Ben AknounAlgeria 1998..

[2] Mohamed Abbas Mahrazi, Economics of Public Finance, University Publications, 2008.

[3] Lahcen Bo Abdullah, Al-Saeed Bin Issa, 2004, p. 230.

[4] [4]Belkacem Slatanih, the sociology configuration of professional and employment policy in the penalty $t$, Journal ofHuman Sciences p 10., Issue 10 p. 131.

[5] Tommy Saleh "Introduction to the theory of economic measurement" University Press Publications 1999. p. 83.

[6] Amoury Hadi Kazem Hasnawi "Methods of Economic Measurement" Dar Wael Publishing Amman - Jordan - 2002, pp. 154-154.

[7] Kadhad Rabeh, Massadur Fares, Unemployment Causes of Treatment and its Impact on Society, Part 2, Research Papers and Papers An Arab symposium held in Al-Azhar from 26 to 28 April 2006., p. 295.

[8] Tariq Abdul Raouf Amer, Causes and Dimensions of Unemployment, Dar Al Yazuri Publishing and Distribution, edition 2, 2015. p. 24.

[9] Abdelkader Mohamed Abdelkader Attia, "Modernization in the econometrics between theory and practice", Alexandria University, Alexandria, 2005, p. 3.

[10] Tariq Abdul Raouf Amer, Causes and Dimensions of Unemployment, Dar Al Yazuri Publishing and Distribution, edition 2, 2015, p. 26.

[11] Tariq Abdul Raouf Amer, Causes and Dimensions of Unemployment, Dar Al Yazuri Publishing and Distribution, edition 2, 2015, p. 36.

[12] Kadhad Rabeh, Massadur Fares, Unemployment Causes of Treatment and its Impact on Society, Part 2, Research Papers and Papers An Arab symposium held in Al-Azhar from 26 to 28 April 2006., p. 296.

[13] Tariq Abdul Raouf Amer, Causes and Dimensions of Unemployment, Dar Al Yazuri Publishing and Distribution, edition 2, 2015., p. 26.

[14] Tariq Abdul Raouf Amer, Causes and Dimensions of
Unemployment, Dar Al Yazuri Publishing and Distribution, edition 2, 2015., pp. 36-37.

[15] Régis BOURBONNAIS \& Jean Claude Usunier; Prévision des ventes -Théorie et Pratiques ; Collection Gestion $3^{\text {ème }}$ édition EC ONOMICA PARIS p 220.

[16] Régis BOURBONNAIS; Econométrie- Manuel et exercices corrigés ; 5 ème édition. DUNOD. 2003 Paris. p 220.

[17] JCUSUNIER; Pratique de la prévision à court terme. Ed DUNOD Paris. 1982. $p 78$.

[18] Dominick salvator, Ph.D. "statistics and economics ". Schaum's Outline Series McGraw-Hill, New York, 2001.

[19] Ahmed Abdel Samie Allam, Public Finance, El-Wafa Legal Library, Alexandria, 2012p. 44.

[20] Mahrazi Mohammed Abbas, Economical Public Finance, University Press Office, 10, 2010., p. 55.

[21] Abdulmutallab Abdel Hamid, The Economics of Public Finance, Dar Al-Jamea Publishing, Alexandria, 2004, 2005., p. P. 95.

[22] Hamid Abdelmajid Darar, Principles of Public Finance, Alexandria, 2008. p. 378.

[23] Mahrazi Mohammed Abbas, Economical Public Finance, University Press Office, 10, 2010, p 61.

[24] Mahrazi Mohammed Abbas, Economical Public Finance, University Press Office, 10, 2010, p66.

[25] Omar Yahyaoui, Contribution to the Study of Public Finance, Dar Printing and Publishing, 2005., p. 42

[26] Said Abdel Aziz, Public Finance, University House Beirut, 2008. pp. 470-471.

[27] Ahmed Abdel Samie Allam, Public Finance, El-Wafa Legal Library, Alexandria, 2012, p. 68.

[28] Khalid Shehada Al Khatib, Ahmed Zuhair Shamia, Foundations of Public Finance, Dar Wael Publishing, Second Edition, Amman, 2005. pp. 61-62.

[29] Ahmed Zuhair Shamia and Khaled Al-Khatib, Public Finance, Dar Zahran Publishing and Distribution, 2013., p. 110.

[30] Mohamed Helmi El-Jilani - Accounting Inflation, Dar Al-Marawood Publishing and Distribution Edition 1, 2014-1435. p20-21.

[31] Majed Ahmed Atallah - Investment Management, Osama Publishing House and Distribution, Jordan, edition 2011-2011., p. 12.

[32] Khaled Wasef Al-Wazzani- Ahmed Hussein Al-Rafei, Principles of Macroeconomics between Theory and Practice, Dar Wael Publishing, 9-2008 Edition p. 249. 